УДК $94:$ [314.1 (476) : 352.9] «1919»

DOI: https://doi.org/10.33782/eminak2019.2(26).292

\title{
УКРАЇНСЬКА ВІЙСЬКОВО-САНІТАРНА МІСІЯ В НІМЕЧЧИНІ Й ТАБОРОВІ ГРОМАДИ ПОЛОНЕНИХ УКРАЇНЦІВ У 1919 р.
}

\author{
Ігор Срібняк ${ }^{1}$, Мілана Срібняк ${ }^{2}$ \\ ${ }^{1}$ Київський університет імені Бориса Грінченка \\ e-mail: i.sribniak@kubg.edu.ua \\ ORCID: https://orcid.org/0000-0001-9750-4958 \\ ${ }^{2}$ Київський національний університет імені Тараса Шевченка \\ e-mail: milana.sribniak@gmail.com \\ ORCID: https://orcid.org/0000-0003-1353-3001
}

\begin{abstract}
У статті йдеться про діяльність Військово-санітарної місії для справ полонених вояків-українців у Німеччині, яка зосередила свої зусилля й на встановленні зв'язків з українськими таборовими громадами та надання їм адресної гуманітарної допомоги від уряду УНР з метою відновлення національно-просвітнищької роботи у середовищі полонених українців. Завдяки цьому навесні-влітку 1919 р. у багатьох таборах були засновані аматорські драмгуртки, школи для неписьменних і малописьменних, бібліотеки, кооперативи. Діяльність Місії у таборах мала об'єктивно позитивні наслідки, засвідчивши готовність уряду УНР прийти на допомогу полоненим українцям у Німеччині.
\end{abstract}

Ключові слова: табір, полонені вояки-українці, Військово-санітарна місія, Німеччина

Перші спорадичні згадки про діяльність українських військово-санітарних місій на теренах Німеччини й Австро-Угорщини з'явились на шпальтах журналу «Воля» ще в часі їх активного функціонування на теренах згадуваних країн ${ }^{1}$. Слід щоправда відзначити, що авторами цих публікацій виступили співробітники цих місій, що дозволяє віднести ці статті радше до категорії джерел. Деякі факти про їх роботу були подані й С. Наріжним у його загальновідомій книзі «Українська еміграція»². Уривчаста інформація про діяльність військово-санітарних місій на теренах центральних держав - але лише у контексті відтворення окремих сторінок історії українських червонохресних організацій - була наведена у низці статей В. Трембіцького3.

Наукова розробка проблеми репатріації полонених вояків-українців з теренів Центральних держав активізувалась у першій половині 1990-х рр., коли зусиллями дослідників історії української дипломатичної служби були спорадично висвітлені й

\footnotetext{
1 Верниволя В. [Сімович В.]. Українська військово-санітарна місія в Німеччині // Воля (Відень). 1919. 29 листопада. Т. V. Ч. 5. С. 212-214; Чайка К. Український Червоний Хрест за кордоном // Воля (Відень). 1920. 4 грудня. T. IV. Ч. 10. С. 482-486.

2 Наріжний С. Українська еміграція. Культурна праця української еміграції між двома Світовими війнами. Прага, 1942. Ч. І. С. 16-17.

3 Трембіцький В. Всеукраїнське Товариство Червоного Хреста 1918-1923 // Вісті комбатанта. Торонто-Нью-Йорк, 1972. Ч. 4 (60). С. 16-21; Трембіцький В. Червоно-хресні взаємини з суміжними державами // Вісті комбатанта. - Торонто-Нью-Йорк, 1973. Ч. 3 (63). С. 87-93; Ч. 4 (64). С. 8-14; Трембіцький В. Лікарський світ за української держави (за Директорії УНР 1919-1920рр.) // Вісті комбатанта. Торонто-Нью-Йорк, 1974. Ч. 1 (65). С. 18-21; Трембіцький В. Українська консульська служба 1918-1924 років // Симон Петлюра. Збірник студійно-наукової конференції в Парижі (травень 1976). Статті, замітки, матеріяли. Мюнхен-Париж, 1976. С. 181-182.
} 
деякі сторінки організації їх повернення додому4. За кілька років до вивчення різних аспектів цієї тематики долучилась ще група істориків, у працях яких була нагромаджена додаткова інформація про особливості репатріаційного процесу полонених та інтернованих українців з теренів кількох європейських держав 5 .

Якісні зміни у вивченні цієї проблеми відбулися з виходом у світ монографії «Полонені та інтерновані вояки-українці в Австро-Угорщині та Німеччині (19141920 рр.)», один розділ якої - «Діяльність українських дипломатичних та військовосанітарних місій по репатріації полонених українців (1918-1920рр.)» був безпосередньо присвячений розкриттю цієї темиб. Безпосередньо дослідженню процесу репатріації полонених вояків-українців з теренів Центральних держав стосувались ще низка публікацій І. Срібняка7. Підсумковий характер мала брошура, для написання якої авторами було залучено значну кількість архівних документів ${ }^{8}$.

Процеси репатріації полонених та інтернованих вояків-українців також були у полі предметного зацікавлення В. Соловйової, яка у рамках своєї дослідницької теми - діяльності дипломатичних представництв українських національних урядів 19171921 рр., зупинилась і на їх зусиллях у справі консульського забезпечення організації перевезення згаданих категорій вояцтва до України‥ Ця тематика розроблялась й іншими дослідниками, праці яких суттєво розширили наші уявлення про специфіку репатріації полонених українців ${ }^{10}$.

\footnotetext{
${ }^{4}$ Вєдєнеєв Д., Табачник Д. Репрезентанти Війська Українського: Сторінки історії військового аташату України доби визвольних змагань // Військо України. 1992-1993. Ч. 2-3. С. 94-100; Ведєнєєв Д.В. Становлення зовнішньополітичної служби України (1917-1920рр.) // Автореф. дис.... канд. іст. наук. Київ, 1994. 17 с.; Вєдєнєєв Д. Рятуючи з полону співвітчизників: 3 історії військовосанітарних місій Української Народної Республіки // Нічна столиця. Київ, 1996. Вип. 3 (3). С. 6.

5 Козлітін В.Д., Ярко Н.А. Українська Народна Республіка і Королівство Сербів, Хорватів і Словенців у 1918-1922 рр. // Міжнародні зв'язки України: наукові пошуки і знахідки. Зб. наук. праць. Київ, 1998. Вип. 7. С. 21-42; Кривець Н.В. Повноважне представництво України у Німеччині (19211923 рр.). // Міжнародні зв'язки України: наукові пошуки і знахідки: Зб. наук. праць. Київ, 1998. Вип. 7. С. 65-82; Вєдєнєєв Д.В., Будков Д.В. Юність української дипломатії. Становлення зовнішньополітичної служби України в 1917-1923 роках. Монографія. Київ, 2006. 312 с.

6 Срібняк І. Полонені українці в Австро-Угорщині та Німеччині (1914-1920рр.). Київ, 1999. С. 159-203.

7 Срібняк І.В. Репатріаційна діяльність українських дипломатичних і військово-санітарних установ у Європі в 1918 р. // Студії з архівної справи та документознавства, 1999, Т. 5. Київ, 1999. С. 259-263; Срібняк І.В. Українська Держава на міжнародній арені: з досвіду діяльності воєнної дипломатії в 1918 р. // Гетьманський альманах / Відп. ред. Ю.І. Терещенко. Київ, 2003. Ч. II. С. 94100; Срібняк І.В. Діяльність Директорії УНР з репатріації полонених вояків-українців з теренів європейських країн (військово-політичний аспект) // Кам'янець-Подільський - остання столиця Української Народної Республіки: Мат-ли Всеукр. наук. конф. Кам'янець-Подільський, 2009. C. 184-192.

${ }^{8}$ Срібняк І., Срібняк М. Українські військово-санітарні місії для справ полонених у Німеччині та Австро-Угорщині (1918-1920рр.): створення, персональний склад, основні напрями діяльності. Київ, 2016. 66 с.

9 Соловйова В.В. Українська дипломатія у країнах центральної Європи 1917-1920 рр. Донецьк, 2004. 170 с.; Соловйова В.В. Дипломатична діяльність українських національних урядів 19171921 рр. Київ, Донецьк, 2006. 394 с.

10 Жванко Л.Н. Евакуація та соціальний захист українських військовополонених доби другого Гетьманату (травень - грудень 1918 р.) // Вісник Харківського політехнічного інституту. Харків, 1999. Вип. 20. С. 16-27; Дацків І.Б. Дипломатія Українських державних утворень у захисті національних інтересів 1917-1923 рр. Тернопіль, 2009. 520 с.; Жванко Л.Н. Украинские военнопленные в государствах Четвёртого Союза: проблемы возвращения домой (1918 год) // Первая мировая война, Версальская система и современность: сб. ст. / отв. ред.: И.Н. Новикова, А.Ю. Павлов, А.А. Малыгина. Санкт-Петербург (Россия). Санкт-Петербург, 2014. С. 94-103.
} 
У 2017 р. до вивчення цієї теми звернувся і В. Заболотнюк, опублікувавши один із своїх сюжетів про діяльність військово-санітарної місії у Німеччині ${ }^{11}$. Як і належиться, він розпочинає свою статтю коротким історіографічним аналізом праць своїх попередників, не згадуючи при цьому багатьох знаних дослідників даної проблематики. Але найпоказовішим $\epsilon$ посилання (у ряду інших праць) на монографію «Обеззброєна, але нескорена: Інтернована Армія УНР у таборах Польщі й Румунії (19211924 рр.)», в якій - як можна зауважити з самої лише назви - апріорі не могло бути жодних згадок про діяльність Військово-санітарної місії у Німеччині! Водночас В. Заболотнюк жодним чином не згадує про цілу низку вже згадуваних публікацій I. Срібняка, у т.ч. й монографічного характеру, які являли собою певний етап у науковій розробці цієї проблематики.

Викликає запитання й запропонована автором статті джерельна основа - 3 незрозумілих причин він не вважає за потрібне звертатись до документів ЦДАВО України, де зберігається найзначніші збірки документів з історії діяльності українських військово-санітарних місій в Німеччині й Австро-Угорщині. Ще одна група заявлених автором джерел (еміграційні часописи) - не викликає, зрештою, жодних застережень, проте серед них чомусь відсутня таборова газета «Шлях», яка видавалась заходами Військової місії в Німеччині у 1919-1920 рр. Між тим, саме матеріали цього видання $\epsilon$ надзвичайно важливим джерелом для відтворення як повсякдення таборових громад полонених українців у цій країні, так і перебігу їх репатріації. Також цілком незрозуміло - для чого В. Заболотнюк згадує у своїй статті про одну із збірок документів ${ }^{12}$, адже в ній відсутні жодні згадки про навіть саме лише існування українських військово-санітарних місій у 1918-1920 pр.

Попри те, що у Вікіпедії представлені окремі гасла про чільних фігурантів і керівників репатріаційних місій у 1918-1920 рр., В. Заболотнюк не вважав за потрібне перевірити відповідність їх прізвищ та імен, внаслідок чого маємо міфічних «Сергія Сиротенка» (треба - Григорій Сиротенко) і «Василя Байду» (треба Василь Байлов або Байлів). Присутні у статті й поодинокі фактологічні неточності, з яких найбільше кидається у вічі фраза: «Голова Товариства Українського Червоного Хреста д-р Андрій Окопенко призначив головою Військово-Санітарної Місії Костя Воєвідку» (c. 236), чого апріорі не могло бути, бо призначення голів місій на початку 1919 p. було винятково прерогативою Директорії УНР (і зокрема його військового міністерства), і таке право було делеговано А. Окопенку тільки у травні 1919 p.13

У своїй наступній статті автор повторив більшість своїх же власних помилок ${ }^{14}$, майже слово в слово переповівши історіографічний огляд зі своєї попередньої статті. Тут В.Заболотнюк знову покликається на монографію «Обеззброєна, але не скорена...», в якій, на його думку, йдеться про репатріацію полонених українців з Німеччини. Далі автор практично без змін подає текст своє першої статті, і лише після цього вмонтовує новий сюжет про «з'їзд представників українських полонених» у Берліні, що відбувся стараннями більшовицької дипломатії у середині червня

\footnotetext{
11 Заболотнюк В. Українська військово-санітарна місія для справ полонених у Німеччині (19181920) // Військово-науковий вісник. Київ, 2017. Вип. 12. С. 21-33.

12 Йдеться про: Українська політична еміграція 1919-1945: Документи і матеріали. Київ, 2008. $928 \mathrm{c}$.

13 Заболотнюк В. Українська військово-санітарна місія... С. 23.

14 Заболотнюк В. Національно-виховна діяльність Української військово-санітарної місії для справ полонених у Німеччині (1918-1920) // Україна та Німеччина: міждержавні відносини: збірник наукових праць. Чернігів, 2018. С. 233-244.
} 
1920 р. Після цього знову йде повтор тексту першої статті, щоправда у самому кінці автор спромігся неістотно розширити висновки до статті, внісши у такий спосіб «поважний» внесок у наукову розробку даної проблеми 15 .

Отже, попри значну кількість дотичних до цієї тематики публікацій, існує потреба подальшого збагачення документально-джерельної бази досліджень репатріаційного процесу в 1918-1920 pр. Метою даної статті $€$ відтворення організаційнодопомогової діяльності Військової місії для справ полонених українців у Німеччині, завдяки якій стало можливим інтенсифікувати національну культурно-освітню роботу в таборах, а також активізувати процес творення українських таборових громад, що гуртували у своєму складі значну кількість вояків-українців. До завдань статті належить визначення особливостей діяльності просвітницьких і мистецьких організацій у таборах, шляхів комунікації Місії із загалом таборян, а також встановлення причин низької результативності роботи української військової дипломатії у справі репатріації полонених вояків-українців.

Військово-санітарна комісія для справ полонених вояків-українців розпочала свою діяльність у Німеччині ще восени 1918 р., маючи своїм головним завданням налагодження процесу їх репатріації. Після приходу до влади Директорії УНР Військова (Військово-санітарна) місія у Німеччині (ВСМуН) продовжила свою роботу, проте проведення репатріації полонених українців у широких масштабах у цей час було значно ускладнено з огляду на цілу низку зовнішньополітичних причин. В силу цього Місія зосередила свої зусилля і на встановленні зв'язків з українськими таборовими громадами задля надання їм адресної гуманітарної допомоги від уряду УНР. Це завдання ускладнювалось тим, що у середині січня 1919 р. процес репатріації полонених українців був фактично припинений на вимогу представників Антанти у Німеччині (у зв'язку з приходом до влади Директорії УНР і тимчасовою невизначеністю основних напрямів її зовнішньої політики).

Наслідком такої заборони став глибокий скепсис, який опанував переважною більшістю полонених українців. Навіть та обставина, що головою культурноосвітнього відділу ВМСуН було призначено відомого українського вченого-філолога й освітянина В. Сімовича, відомого майже всім таборянам з огляду на його кількалітній досвід просвітницької роботи в таборах полонених українців у Німеччині, не могла подолати негативізму в головах бранців, спричиненого затримкою їх від'їзду додому.

Попри такі настрої Місія активно розпочала свою діяльність, надаючи істотну моральну та гуманітарну допомогу полоненим воякам-українцям, які продовжували залишатись у таборах Німеччини. У центрі її уваги весь час перебувала найчисельніша - з числа усіх інших - таборова українська громада у Зальцведелі, громадськонаціональне життя якої виявлялось найінтенсивніше ${ }^{16}$.

Водночас Місія спрямовувала значну матеріальну допомогу й іншим громадам

15 Заболотнюк В. Національно-виховна діяльність... - С. 235-238, 240.

16 Докладніше про це див.: Срібняк І., Срібняк М. Діяльність Військово-санітарної місії для справ полонених вояків-українців у таборі Зальцведель, Німеччина (1919 - перша половина 1920 рр.) // Вісник Маріупольського державного університету. Серія: «Історія, політологія». Маріуполь, 2019. Вип. 24. 
полонених українців у Німеччині. До цього числа належала українська організація в таборі Кведлінбург, в якому 7 березня 1919 р. заходами ВСМуН було скликано віче (у присутності 1075 таборян). Під час його роботи було ухвалено рішення про заснування Української громади, обрано ії̈ раду на чолі з А. Михайленком (пізніше - Федором Хижняком). Також був визначений і план діяльності української організації, який передбачав започаткування роботи хору, театру та школи грамоти.

Вже за місяць до складу Громади вписалось 1331 таборян і ця кількість продовжувала збільшуватись. За цей час у таборі розвинуло свою діяльність драматичне товариство «Український театр ім. Т.Г.Шевченка», яке, спираючись на фінансову підтримку Mісії (1000 марок німецьких (м.н.) щомісячно) ${ }^{17}$, та завдяки активній роботі своїх 24-х членів зуміло облаштувати приміщення театру та 16 квітня 1919 р. підготувати свій перший виступ ${ }^{18}$.

Влітку 1919 р. громада успішно провадила свою діяльність, попри надходження невтішних вісток про тимчасову неможливість проведення репатріації полонених українців з теренів Німеччини. У таборі діяла школа (староста - Григорій Лучко), якою опікувалася рада табору і таборовий театр. Помітним культурним явищем у житті табору були вистави, які готувались акторами-аматорами Драматичного товариства імені Т.Г. Шевченка, яке дбаючи про нужденних таборян - частину вхідних квитків розповсюджувало безкоштовно. Полонені мали можливість випозичати книги з таборової бібліотеки та відвідувати виклади з історіїУкраїни ${ }^{19}$.

Все це стало можливим завдяки матеріальній допомозі ВСМуН і регулярному надісланню книг до бібліотеки. Крім того, Місія фінансово підтримувала й членів ради табору, до складу якої входили Петро Хвилько (писар), Даценко (скарбник), Дм. Новак (бібліотекар), Хижняк, Цистан, Лучко та Кучма. Невеликі грошові квоти виділялись хворим полоненим (за їх заявами). У вересні 1919 р. така допомога склала 170 м.н., ще 420 м.н. було надіслано поштою до табору Бранденбург на потреби тамтешніх українців. Ще близько 100 м.н. було передано хворим таборянам у Кведлінбурзі 20.

Час від часу табір відвідував В. Сімович, від якого полонені дізнавались про військово-політичне становище України. Під час його чергового приїду до табору (11 серпня 1919 р.) він запропонував членам ради обрати двох делегатів для поїздки до Вецляра «на свято відкриття пам'ятника Бранцям Українцям». Для виконання цієї місії були обрані полонені Яків Даценко і Дмитро Новак, яким було авансовано на цю подорож 110 м.н. ${ }^{21}$

У кінці серпня 1919 р. таборова школа в Кведлінбурзі опинилась у складному становищі через відсутність помешкання та вчителя для проведення у ній викладів. Щойно вдалося вирішити ці проблеми (викладати у школі погодився П. Хилько), як комендатура зажадала у середині вересня перенести школу та театр до інших бараків. Разом з об'єктивними труднощами мали місце й суб’єктивні - коли доцільність деяких здійснених радою витрат була сумнівною. Про це опосередковано свідчить те, що у середині вересня школі гостро забракло найнеобхідніших речей (олівців,

\footnotetext{
17 ЦДАВО України. Ф. 3696. Оп. 2. Спр. 305. Арк. 18.

18 Новохацький П. Із діяльности Драматичного Товариства «Український Театр ім. Т.Г. Шевченка» у таборі полонених Кведлінбург // Шлях (Зальцведель). 1919. 1 жовтня. Ч. 61.

19 ЦДАВО України. Ф. 4465. Оп. 1. Спр. 1024. Арк. 3, 4-4зв., 5.

20 ЦДАВО України. Ф. 4465. Оп. 1. Спр. 1024. Арк. 8-9, 10зв., 11-11зв., 15.

21 ЦДАВО України. Ф. 4465. Оп. 1. Спр. 1024. Арк. 1-3.
} 
зошитів та ін.), а у ради не було коштів для їх придбання. У цій ситуації рада вирішила звернутись до таборового Драматичного товариства з проханням виділити для цієї мети 100 м.н. ${ }^{22}$ (таборовий театр був фактично єдиним прибутковим товариством у таборі).

Лише один перелік поставлених до 15 вересня 1919 р. таборовим драматичним товариством вистав: «На першій гулі» Васильченка, «Назар Стодоля» Т.Шевченка, «Тарасова ніч» О. Кобця, «Цивільний шлюб», «Юрко Огневик» (обидві - Левченка), «Сватання на Гончарівці» Г. Квітки-Основ’яненка, «Помирились», «По ревізії», «Лихо не кожному лихо - іншому й талан», «Дай серцеві волю, заведе в неволю», «Невольник», «Наймичка» (всі М. Кропивницького), «Хатня революція», «Хазяїн», «Бурлака», «Бондарівна», «Мартин Боруля», «Розумний і дурень» (всі І. Тобілевича) й ін. свідчить про успішність його діяльності. Кожна з цих п'єс виставлялася 2-4 рази, причому кожного разу в театрі не було вільних місць, що пояснювалося мистецькою грою акторів-аматорів та участю у виставах таборового оркестру. Попри обмеженість власних коштів, управа товариства безкоштовно розповсюджувала серед полонених $2 / 3$ вхідних квитків на кожну виставу, а також надавала відчутну грошову допомогу хворим з таборового шпиталю23.

У другій половині вересня 1919 р. німецька влада ухвалила рішення про перевезення полонених українців з Кведлінбурга до Зальцведеля. Станом на 23 вересня 1919 р. у таборі перебувало 200 українців (у списках української громади загалом фігурувало 624 особи). 1 жовтня відбулось ліквідаційне засідання ради української громади табору Кведлінбург, члени якої мали бути перевезені до Зальцведеля, а все майно громади було передано ВСМуН 24 .

Ще кілька українських громад були засновані на початку березня 1919 р. у таборах Цербст (голова Ради організації - К. Лукіянович), Франкфурті-на-Одері (голова П. Шишенок) та Сольтау. 14 березня 1919 р. на вічі українців у таборі Штаргард (Померанія) було «вирішено зорганізуватися в окрему громаду задля національного економічного і громадянського освідомлювання земляків» та обрано раду на чолі $з$ В. Шапошником. Тоді ж була заснована й «Українська Громада» у таборі полонених офіцерів російської армії Вільдеман, до якої входили й солдати цього табору. Головою Громади було обрано капітана Четвертака, писарем П. Іваненка.

Наприкінці березня 1919 р. у таборах Заган (Сілезія) і Мінхенберг полоненими українцями також були засновані українські громади (голови - П.Лозовський і Ф. Патика), тоді ж були створені національні комітети у таборах Бавцен, Хемніц і Целлє, що мали підготувати грунт для заснування українських організацій у цих таборах. У квітні постали українські громади у таборах Рулєбен і Нойгамер. На початку червня 1919 р. у таборі Бранденбург було засновано український комітет, який встановив сталий зв'язок з місією, 20 вересня у таборі Мінден заснувалася українська громада на чолі радою (у складі Т. Коновала, В. Галецького та С. Слюсаренка), яка об'єднала близько 100 вояків-українців ${ }^{25}$.

Поряд з процесом виникнення громад у таборах спостерігалося пожвавлення всіх сторін життя вже існуючих українських організацій. Так, зокрема, у таборі Цербст

\footnotetext{
22 ЦДАВО України. Ф. 4465. Оп. 1. Спр. 1024. Арк. 12-12зв.

23 Новохацький П. Вказ. праця.

24 ЦДАВО України. Ф. 4465. Оп. 1. Спр. 1024. Арк. 13зв., 16.

25 Шлях (Зальцведель). 1919. 8 березня. Ч. 4; 2 квітня. Ч. 10; 5 квітня. Ч. 11; 26 квітня. Ч. 16;

3 травня. Ч. $17-18 ; 14$ травня. Ч. $21 ; 25$ червня. Ч. $33 ; 1$ жовтня. Ч. $61 ; 11$ жовтня. Ч. 64.
} 
при громаді була заснована українська кооперативна крамниця, яка тільки за 9 днів своєї роботи отримала 1120 м.н. прибутку, а 31 серпня 1919 р. тут було організоване драматичне товариство «Київ», члени якого активно взялися за роботу з виготовлення декорацій. У таборі Вецляр відновили свою діяльність музично-драматичний гурток імені М. Лисенка та науково-просвітній гурток. При українському комітеті у таборі Пархім діяв драматичний гурток, хор, серед полонених провадилась жвава освітня робота.

Українське товариство «Поступ» у таборі Дельменгорст відкрило школу для неписьменних. У вересні 1919 р. у таборах Нойгамер і Губен українськими громадами були створені щоденні школи грамоти, які відвідувало 59 учнів; у таборах діяли бібліотеки, проводились виклади з географії та історії України, фізики й агрономії26. У таборах Цербст і Целлє у липні 1919 р. були засновані драматичні гуртки, які підготували кілька вистав. Театри постали й у таборах Губен, Франкфурт; у таборі Штутгард театральний гурток розпочав свої виступи виставою «Хатня революція» І. Тобілевича ${ }^{27 .}$

Для уможливлення діяльності всіх цих українських організацій ВСМуН виділяла значні кошти (з цільовим призначенням) для допомоги полоненим у таборах, зокрема таборова громада Зальцведеля отримала у лютому-березні 1919 р. 15 тис. м.н., у травні та серпні - ще 10 тис. м.н. Незалежно від цього окремі грошові квоти також спрямовувались Місією на потреби театру, школи та бібліотеки, а також культурнопросвітнього комітету ${ }^{28}$. Також місія надавала фінансову підтримку українським громадам у Вецлярі, Котбусі, Шпротау, Мерзебурзі, Цербсті, Рулебені, Гамельні (всі у Німеччині), 5 тис. м.н. було одноразово передано полоненим українцям одного 3 таборів Данії 29.

Протягом березня-червня 1920 р. місія витрачала кошти для видавництва часопису «Шлях» (загалом - 39541 м.н.) та різних брошур та книжок, підтримувала діяльність українських театрів у таборах (12952 м.н.), оплачувала роботу вчителів у таборових школах (2220 м.н.), приходила на допомогу полоненим в інших випадках, влаштовуючи скажімо, концерти у таборах та призначаючи весь збір від їх проведення - на освітні ціліз ${ }^{30}$.

Проте восени 1919 р. настрої більшості полонених українців змінились - небажання великих держав піти назустріч їх прагненню скорішого виїзду додому призвело до крайнього ступеню розчарування у душах таборян. За повідомленням часопису «Шлях» загальний настрій українського вояцтва восени 1919 р. був у таборах надзвичайно пригнобленим - «зневірря й озлоблення досягло найвищого ступеня [...] полонені, голі і босі, на милість долі [...] [були] покинуті зимувати у дірявих бараках» ${ }^{31}$.

Голова української громади у таборі Ерланген С. Квотченко у своєму листі до редакції «Шляху» писав: «П'ять років минуло, як ми несемо тягар неволі на своїх вимучених плечах [...]. Війна вже давно скінчилась, всі полонені, які перебували в Німеч-

\footnotetext{
26 Шлях (Зальцведель). 1919. 14 травня. Ч. 21; 24 травня. Ч. 24; 11 червня. Ч. 29; 21 червня. Ч. 32; Ілюстрований додаток. 30 липня. Ч. 3; Ілюстрований додаток. 17 вересня. Ч. 5; 22 листопада. Ч. 76; 31 грудня. Ч. 86.

27 Таборові театри // Шлях (Зальцведель). 1919. 22 жовтня. Ч. 67.

${ }^{28}$ ЦДАВО України. Ф. 3192. Оп. 2. Спр. 3. Арк. 9зв.-10зв.

29 ЦДАВО України. Ф. 3192. Оп. 2. Спр. З. Арк. 9зв.

30 ЦДАВО України. Ф. 3192. Оп. 2. Спр. 3. Арк. 18зв.-19.

313 життя полонених українців у Німеччині // Шлях (Зальцведель). 1919. 4 жовтня. Ч. 62.
} 
чині, давно вже повернули своїх країв [...] лише ми сидимо тут і не маємо надії на скорий поворот до рідного краю [...]. Ми більше нічого не бажаємо, як тільки виїхати до рідного краю. Нехай там буде неспокій, хай буде голод, але нам лекше буде це переносити в рідному краю і на волі, як тут, і в неволі» 32 . У цей час значно погіршилося і харчування полонених українців - їх денний раціон в окремих таборах зменшився до 175 грам хліба і 60 грам жирів, що фактично прирікало їх на голодну смерть. На жаль, ВСМуН у цей час була обмежена у своїх можливостях надавати таборовим громадам матеріальну допомогу, бо восени 1919 р. суттєво скоротились обсяги фінансування Місії від уряду УНР.

Отже, завдяки моральній і матеріальній допомозі, яка надавалася полоненим українцям Військово-санітарною місією у Німеччині у 1919 р. стало можливим спочатку відновити, а згодом й значно інтенсифікувати національне та культурноосвітнє життя у таборах. Заходами Місії у таборах засновувались українські громади, які, у свою чергу, організовували для полонених школи грамоти, театральні та музично-хорові гуртки, кооперативи. Місії вдалось забезпечити ефективну комунікацію з полоненими завдяки започаткуванню видання часопису «Шлях». Останній регулярно повідомляв своїх читачів про життя таборових українських громад, інформуючи у свойй постійній рубриці «3 життя полонених у Німеччині» про їх найвизначніші досягнення.

Проте вже взимку 1919 р. ситуація у таборах почала змінюватись не на користь ВСМуН, якій так і не вдалось організувати регулярне перевезення додому полонених українців. Розчарування таборян результатами діяльності Місії було настільки значним, що значна частина з них - зневірившись - не бажали чути жодних аргументів з уст українських дипломатів. Особливо лякала таборян перспектива чергового зимування у непристосованих для цього бараках, до того ж - в умовах дуже обмеженої кількості пропозицій для працевлаштування. Їх серця огорнув розпач, і це створило сприятливий грунт для проведення більшовицької агітації у середовищі полонених українців, які втрачали віру в ідеали УНР.

Починаючи з травня 1920 р. більшовики вдалися до проведення широкомасштабної репатріації полонених українців (на той час вони набули статусу інтернованих), наслідком чого стало припинення останніми будь-яких контактів з українськими дипломатами. Зрештою, влітку того ж року Військово-санітарна місія була ліквідована у зв'язку з цілковитим припиненням фінансування з боку уряду УНР, а справа надання допомоги колишнім полоненим українцям була передана українському дипломатичному представництву в Німеччині.

\section{REFERENCES}

Chaika, K. (1920). Ukrainskyi Chervonyi Khrest za kordonom [Ukrainian Red Cross Abroad]. Volia, IV, 10, 482486 [in Ukrainian].

Datskiv, I.B. (2009). Dyplomatiia Ukrainskykh derzhavnykh utvoren u zakhysti natsionalnykh interesiv 1917$1923 r r$. [Diplomacy of Ukrainian State Institutions in the Protection of National Interests of 1917-1923]. Ternopil [in Ukrainian].

Kozlitin, V.D. \& Yarko, N.A. (1998). Ukrainska Narodna Respublika i Korolivstvo Serbiv, Khorvativ i Sloventsiv u 1918-1922 rr. [Ukrainian People's Republic and the Kingdom of Serbia, Croats and Slovenes in 1918-1922] Mizhnarodni zviazky Ukrainy: naukovi poshuky i znakhidky, 7, 21-42 [in Ukrainian].

Kryvets, N.V. (1998). Povnovazhne predstavnytstvo Ukrainy u Nimechchyni (1921-1923 rr.) [Plenipotentiary Representation of Ukraine in Germany (1921-1923)] Mizhnarodni zviazky Ukrainy: naukovi poshuky i znakhidky, 7, 65-82 [in Ukrainian].

32 Шлях (Зальцведель). 1919. 25 жовтня. Ч. 68. 
Narizhnyi, S. (1942). Ukrainska emigratsiia. Kulturna pratsia ukrainskoi emigratsii mizh dvoma Svitovymy viinamy [Ukrainian emigration. Cultural work of Ukrainian emigration between the two World Wars]. Praha [in Ukrainian].

Novokhatskyi, P. (1919). Iz diialnosty Dramatychnoho Tovarystva «Ukrainskyi Teatr im. T.H. Shevchenka» u tabori polonenykh Kvedlinburg [From the activities of the Drama Society «Ukrainian Theater by named T. Shevchenko» in the prison camp Quedlinburg] Shlyakh, 61 [in Ukrainian].

Soloviova, V.V. (2004). Ukrainska dyplomatiia u krainakh tsentralnoi Evropy 1917-1920 rr. [Ukrainian diplomacy in the countries of central Europe 1917-1920]. Donetsk [in Ukrainian].

Soloviova, V.V. (2006). Dyplomatychna diialnist ukrainskykh natsionalnykh uriadiv 1917-1921 rr. [Diplomatic activity of the Ukrainian national governments 1917-1921]. Kyiv-Donetsk. [in Ukrainian].

Sribniak, I. (1999). Poloneni ukraintsi v Avstro-Uhorshchyni ta Nimechchyni (1914-1920 rr.) [Prisoners of Ukrainians in Austria-Hungary and Germany (1914-1920)]. Kyiv. [in Ukrainian].

Sribniak, I.V. (1999). Repatriatsiina diialnist ukrainskykh dyplomatychnykh i viiskovo-sanitarnykh ustanov u Evropi v $1918 \mathrm{r}$. [Repatriation activities of Ukrainian diplomatic and military institutions in Europe in 1918]. Studii z arkhivnoi spravy ta dokumentoznavstva, 5, 259-263 [in Ukrainian].

Sribniak, I.V. (2003). Ukrainska Derzhava na mizhnarodnii areni: z dosvidu diialnosti voennoi dyplomatii v $1918 \mathrm{r}$. [Ukrainian State on the International Scene: from the experience of military diplomacy in 1918]. Hetmanskyi almanakh, II, 94-100 [in Ukrainian].

Sribniak, I.V. (2009). Diialnist Dyrektorii UNR z repatriatsii polonenykh voiakiv-ukraintsiv z tereniv evropeiskykh krain (viiskovo-politychnyi aspekt) [The activities of the Directorate of the UNR on the repatriation of captive Ukrainian soldiers from the European countries (military-political aspect)]. In Materialy Vseukrainskoi naukovoi konferentsii Kamianets-Podilskyi (pp. 184-192) [in Ukrainian].

Sribniak, I., Sribniak, M. (2016). Ukrainski viiskovo-sanitarni misii dlia sprav polonenykh u Nimechchyni ta Avstro-Uhorshchyni (1918-1920 rr.): stvorennia, personalnyi sklad, osnovni napriamy diialnosti [Ukrainian military-sanitary missions for the captives in Germany and Austria-Hungary (1918-1920): creation, personal composition, main directions of activity]. Kyiv [in Ukrainian].

Sribniak, I., Sribniak, M. (2019). Diialnist Viiskovo-sanitarnoi misii dlia sprav polonenykh voiakiv-ukraintsiv u tabori Zaltsvedel, Nimechchyna (1919 - persha polovyna 1920 rr.) [Activities of the Military Sanitary Mission for the affairs of captives of Ukrainian soldiers in the camp of Salzwedel, Germany (1919 - first half of 1920)]. Visnyk Mariupolskoho derzhavnoho universytetu. Seriia: «Istoriia, politolohiia», 24 [in Ukrainian].

Trembitskyi, V. (1972). Vseukrainske Tovarystvo Chervonoho Khresta 1918-1923 [All-Ukrainian Society of the Red Cross 1918-1923]. Visti kombatanta, 4 (60), 16-21 [in Ukrainian].

Trembitskyi, V. (1973). Chervono-khresni vzaemyny z sumizhnymy derzhavamy [Red-Cross Relations with the Neighboring States]. Visti kombatanta, 3 (63), 87-93; 4 (64), 8-14 [in Ukrainian].

Trembitskyi, V. (1974). Likarskyi svit za ukrainskoi derzhavy (za Dyrektorii UNR 1919-1920 rr.) [Doctoral world for the Ukrainian State (under the Directory of the UNR 1919-1920)]. Visti kombatanta, 1 (65), 1821 [in Ukrainian].

Ukrainska politychna emihratsiia 1919-1945: Dokumenty i materialy (2008). [Ukrainian Political Emigration 1919-1945: Documents and Materials]. Kyiv [in Ukrainian].

Vernyvolia, V. [Simovych, V.]. (1919). Ukrainska viiskovo-sanitarna misiia v Nimechchyni [Ukrainian Military Sanitary Mission in Germany]. Volia, V. 5, 212-214 [in Ukrainian].

Vedeneev, D. \& Tabachnyk, D. (1992-1993). Reprezentanty Viiska Ukrainskoho: Storinky istorii viskovoho atashatu Ukrainy doby vyzvolnykh zmahan [Representatives of the Ukrainian Army: Pages of the history of the military attache of Ukraine during the period of liberation struggles]. Viisko Ukrainy, 2-3, 94-100 [in Ukrainian].

Vedeneev, D.V. (1994). Stanovlennia zovnishnopolitychnoi sluzhby Ukrainy (1917-1920 rr.) [Formation of the Foreign Policy Service of Ukraine (1917-1920)]. (Extended abstract of Candidate's thesis). Kyiv [in Ukrainian].

Vedeneev, D. (1996). Riatuiuchy z polonu spivvitchyznykiv: Z istorii viiskovo-sanitarnykh misii Ukrainskoi Narodnoi Respubliky [Remaining from the captivity of compatriots: From the history of military-sanitary missions of the Ukrainian People's Republic]. Nichna stolytsia, 3(3), 6 [in Ukrainian].

Vedeneev, D.V. \& Budkov, D.V. Yunist ukrainskoi dyplomatii. Stanovlennia zovnishnopolitychnoi sluzhby Ukrainy $v$ 1917-1923 rokakh [Youth of Ukrainian diplomacy. The formation of the foreign policy service of Ukraine in 1917-1923]. Kyiv [in Ukrainian].

Zabolotniuk, V. (2017). Ukrainska viiskovo-sanitarna misiia dlia sprav polonenykh u Nimechchyni (19181920) [Ukrainian Military Sanitary Mission for the Prisoners in Germany (1918-1920)]. Viiskovo-naukovyi visnyk, 12, 21-33 [in Ukrainian]. 
Zabolotniuk, V. (2018). Natsionalno-vykhovna diialnist Ukrainskoi viiskovo-sanitarnoi misii dlia sprav polonenykh u Nimechchyni (1918-1920) [National-educational activity of the Ukrainian military-sanitary mission for cases of captives in Germany (1918-1920)]. In Ukraina ta Nimechchyna: mizhderzhavni vidnosyny: zbirnyk naukovykh prats (pp. 233-244). Chernihiv [in Ukrainian].

Zhvanko, L.N. (1999). Evakuatsiia ta sotsialnyy zakhyst ukrainskykh viiskovopolonenykh doby druhoho Hetmanatu (traven - hruden $1918 \mathrm{r}$.) [Evacuation and social protection of Ukrainian prisoners of war of the Second Hetmanate (May-December 1918)]. Visnyk Kharkivskoho politekhnichnoho instytutu, 20, 16-27 [in Ukrainian].

Zhvanko, L.N. (2004). Ukrainskie voiennoplennye v gosudarstvakh Chetvortogo Soiuza: problemy vozvrashcheniia domoi (1918 god) [Ukrainian prisoners of war in the States of the Fourth Union: the problem of returning home (1918)]. In Novikova, I., Pavlov, A., Malygina, A. (ed.). Pervaia mirovaia voina, Versalskaia sistema i sovremennost (pp. 94-103). Sankt-Peterburg [in Russian].

\section{Ihor Sribniak}

(Borys Grinchenko Kyiv University, Kyiv, Ukraine)

ORCID: https://orcid.org/0000-0001-9750-4958

Milana Sribniak

(Taras Shevchenko National University of Kyiv, Kyiv, Ukraine)

ORCID: https://orcid.org/0000-0003-1353-3001

\section{Ukrainian Military and Sanitary Mission in Germany and Camp Communities of Captive Ukrainians in 1919}

The relevance of the paper is in the need to define the contribution of Ukrainian military diplomacy in Germany to the repatriation process of captive Ukrainian soldiers in 1919.

The goal of the paper is to describe the organizational and assistance activities of the Military (Military and Sanitary) Mission for the affairs of captive Ukrainians in Germany, which made it possible to strengthen the national cultural and educational work in the camps, and to intensify the process of establishing Ukrainian camp communities which united a significant number of Ukrainian soldiers.

The objectives of the paper include the definition of the peculiarities of the educational and artistic organizations activities in the camps, the ways of communication of the Mission with the campers, as well as the finding out of the reasons of low effectiveness of Ukrainian military diplomacy work on the repatriation of captive Ukrainian soldiers.

The repatriation of captive Ukrainians in 1919 was considerably complicated due to a number of foreign policy reasons, taking into account the fact that the Mission also concentrated its efforts on establishing links with Ukrainian camp communities and providing them with target humanitarian assistance from the Government of the UNR. As a result, it had become possible to restore and subsequently significantly intensify national, cultural and educational life in Quedlinburg, Zerbst, Frankfurt (Oder), Soltau, Stargard, Zagan, Müncheberg, Bautzen, Chemnitz, Celle, and other camps.

Thanks to the activities of the Mission in mentioned and other camps Ukrainian communities were established, which, in turn, organized schools of literacy, drama and music-chorus circles, libraries, and cooperatives for captives. The Mission succeeded in ensuring effective communication with the captives by launching the publication of the magazine «Shlyach». It regularly informed its readers about the life of Ukrainian camp communities, giving the information about their most significant achievements in its permanent column «From the Life of the Captives in Germany».

Thus, the Mission's activities in the camps had objectively positive effects, showing the readiness of the Government of the UNR to come to the aid of captive Ukrainians in Germany.

Keywords: camp; captive Ukrainian soldiers; Military and Sanitary Mission; Germany 